\title{
Microgram per Kilogram
}

National Cancer Institute

\section{Source}

National Cancer Institute. Microgram per Kilogram. NCI Thesaurus. Code C67396.

A unit of a mass fraction expressed as a number of micrograms of substance per

kilogram of mixture. The unit is also used as a dose calculation unit. 